\title{
Impact of Consumer Satisfaction on Fresh E-commerce Repeat Purchase Behavior
}

\author{
Xi Sun ${ }^{1}$ \\ 1. Beijing University of Agriculture, Beijing, 102206, China
}

\begin{abstract}
Fresh e-commerce appeals to consumers with its fast speed, easy operation, low price and various types in the field of fresh. However, the fresh e-commerce market is facing unprecedented competitive pressure. The repeat purchase behavior of consumers has become the focus of fresh e-commerce enterprises. Based on the literature research of consumer satisfaction and fresh e-commerce repeat purchase behavior, through the investigation of online shopping experience of consumers using fresh e-commerce and empirical research on the relationship between consumer satisfaction and fresh e-commerce repeat purchase, this paper puts forward some suggestions to improve consumer satisfaction and increase fresh e-commerce repeat purchase rate.
\end{abstract}

\section{Introduction}

Fresh e-commerce appeals to consumers with its fast speed, easy operation, low price and various types in the field of fresh. The rigid demand and high demand of fresh products attract many consumers. According to Nielsen's data, Chinese consumers buy fresh food three times a week on average, which is 0.5 times higher than the global average. China's fresh food market has a huge scale and broad development prospects. From 2011 to 2017, the transaction volume of China's fresh food market increased from 1168.7 billion Yuan to 1789.7 billion Yuan, and is expected to exceed 500 million Yuan in 2020. With the rapid development of China's fresh retail industry, the clarity of urban planning and the change of regional functions, the traditional fresh shopping place "fresh market", which is easy to be labelled as dirty, messy and poor, is being rectified or even banned. Due to the problems of self-management, changes in consumer demand, dislocation of urban management and other factors, according to the Ping'an Securities, the fresh market's market share of traditional fresh vegetable market has dropped from $62.3 \%$ in 2014 to $56.3 \%$ in 2019 due to its backward facilities, poor sanitary environment, limited self-management and supply categories, and high difficulty in price control and food traceability management. It is expanding to supermarkets and supermarkets in modern channels Transfer of online fresh food purchase mode. At the same time, the popularity and joint application of the Internet and smart phones also accelerate the penetration of the Internet in consumers. The rapid development of e-commerce industry promotes the blowout development of mobile network app and the increase of online shopping scale.

Therefore, the changes of urban functions, the transformation of traditional vegetable market to supermarket and online fresh purchasing channels, the popularity of network and smart phones, and the rise of online shopping have all played a role in promoting the development prospect of fresh e-commerce shopping. However, as the fresh e-commerce market is facing unprecedented competitive pressure, the repeat purchase behavior of consumers has become the focus and hot spot of fresh e-commerce.

\section{Literature review}

Many studies have shown that satisfaction affects consumer repeat purchase intention and behavior.

Liu Jing (2011) believes that service quality is positively related to consumer satisfaction, and depends on the expectation of products or services. Therefore, enterprises try their best to meet or even exceed consumers' expectations, so as to improve consumers' satisfaction [1]. Kim and Lim (2001) found that factors such as entertainment, reliability, information quality and speed play an important role in customer shopping behavior [2]. Zhang Kezhen (2020) believes that the factors affecting the consumer satisfaction of fresh ecommerce platform include five modules: payment system of fresh e-commerce platform, settled merchants, fresh products and logistics transportation[3]. Wang Yun (2021) pointed out that product selection and supply, shopping convenience, quality of fresh agricultural products, entertainment experience and Website Trust are positively and significantly correlated with consumer satisfaction[4].

Cao Huarui (2014) pointed out that the determinants of repurchase intention include the completeness of the delivered goods, the scope of delivery, the accuracy and time of delivery [5]. Shi Yinghong (2020) pointed out that 
customization service quality, response service quality, order completion quality and error handling quality have a significant positive impact on customer repurchase intention[6]. Xing Wenxiang and Han Hua (2014) pointed out that the diversification and personalization of products, product quality, customer evaluation, store reputation, transaction security, website reputation, payment and distribution methods, friendly shopping interface and service all affect consumers' online repeat purchase behavior[7]. Ye Zuoliang, Wang Xueqiao, Bao Zhihong et al. (2011) pointed out that the number of customers who become repeat customers is the result of customers' multiple purchase choice behavior, and customers' repeated purchase behavior is determined in multiple decision-making events of buying and not selling [8].

From the analysis of the above literature, we find that consumers' satisfaction with purchasing behavior is related to consumers' repeated purchasing intention and behavior. At the same time, the service quality, order completion quality, complete commodity categories, distribution completion, consumers' expectation and perception of the differences all affect consumers' satisfaction with the business, and then affect consumers' repeat purchase behavior.

\section{Survey of online shopping experience of fresh e-commerce}

In the survey of online shopping frequency of fresh ecommerce, 100 consumers with fresh e-commerce experience were selected, including 29 males and 71 females. In terms of age distribution, $25-45$ years old is the main force of fresh e-commerce shopping, reaching $75 \%$. In terms of the purchasing frequency of fresh e-commerce, $52 \%$ of them buy fresh online once or twice a week, and $42 \%$ of them buy fresh online three times or less a month. In terms of purchasing fresh categories, aquatic products, meat, poultry, eggs, milk and dairy products are mainly purchased by fresh E-commerce, while vegetables and fruits only account for $29 \%$ and $31 \%$. The data are shown in Table 1 .

Table1. Survey of online shopping experience of fresh e-commerce

\begin{tabular}{|c|c|c|c|}
\hline Title & Option & Frequency & Percentage \\
\hline \multirow{2}{*}{ Gender } & Male & 29 & 29.0 \\
\hline & Female & 71 & 71.0 \\
\hline \multirow{5}{*}{ Age } & Aged from 18 to 25 & 3 & 3.0 \\
\hline & Aged from 25 to 35 & 43 & 43.0 \\
\hline & Aged from 35 to 45 & 32 & 32.0 \\
\hline & Aged from 45 to 60 & 14 & 14.0 \\
\hline & Aged more than 60 & 8 & 8.0 \\
\hline \multirow{3}{*}{$\begin{array}{l}\text { Online } \\
\text { shopping } \\
\text { frequency }\end{array}$} & Once or twice a week & 52 & 52.0 \\
\hline & Three times a month or less & 42 & 42.0 \\
\hline & Once in a while & 6 & 6.0 \\
\hline \multirow{5}{*}{$\begin{array}{l}\text { Type of Fresh } \\
\text { food }\end{array}$} & Vegetable & 59 & 59.0 \\
\hline & Fruit & 40 & 40.0 \\
\hline & Frozen aquatic products & 100 & 100.0 \\
\hline & Meat and egg & 100 & 100.0 \\
\hline & Milk and dairy products & 100 & 100.0 \\
\hline
\end{tabular}

From the above research, we find that: first, consumers who have had the experience of fresh e-commerce purchase are more recognized for the business of fresh ecommerce purchase and delivery to home, with a high rate of repeat purchase. Second, in terms of age division, young and middle-aged people are the main force. This part of the population across the age of ten years is the main force of young and middle-aged people who have just graduated and entered the society to give consideration to life and family. The common characteristics of this group of people are high work pressure, tight time, and need to take into account family and career. At the same time, young and middle-aged people have certain requirements for the quality and variety of food materials, and pursue the quality of life. They are not particularly price sensitive people, but they have less time for daily shopping. Third, in terms of purchasing frequency, purchasing once or twice a week or several times a week also shows that this part of the population has a high repeat purchase rate and a large demand for fresh products. Most of them are family members with the characteristics of daily home catering. Fourth, in terms of purchasing categories, it mainly focuses on frozen fresh aquatic products, meat, poultry and eggs, milk and dairy products, while in terms of purchasing vegetables and fruits, it still accounts for 50\% of the total number of buyers, but the quantity of purchasing frozen fresh aquatic products, meat, poultry 
and eggs, milk and dairy products first is less. This also shows that on the one hand, the community supply of fruits and vegetables is relatively convenient, and there are relatively more fruit and vegetables shops in or around the community, which is convenient for consumers to purchase nearby. On the other hand, the vegetables and fruits of fresh e-commerce platform are mostly pure vegetables and fruits or high-quality vegetables and fruits, and the prices are relatively expensive. Meanwhile, vegetables and fruits are more perishable and vulnerable than other frozen and fresh commodities, and they are quite different from the photos provided by the ecommerce platform. Therefore, some consumers who are convenient for daily off-duty shopping will choose offline shopping.

\section{Related survey of consumer satisfaction and fresh e-commerce repeat purchase}

In the survey of 100 consumers who have had the experience of fresh online shopping, it is found that $72 \%$ of consumers want to deliver within half an hour, and the remaining $28 \%$ of consumers want to deliver according to the appointment time, which indicates that the delivery time has a great impact on consumers, and more consumers require time efficiency or deliver according to the specified time. Among these consumers, the online purchase frequency of fresh food is still relatively high, with $48 \%$ purchasing once a half month and $35 \%$ purchasing once or more a week. Among these buyers, the majority of consumers pay attention to both the quality and the price of goods, accounting for $76 \%$ of the total number. $24 \%$ of consumers pay more attention to the quality of goods, but no consumers say that they will ignore the quality of fresh goods because of the price. When consumers choose to buy fresh products on the platform, they don't care about whether they are selfoperated products on the platform, but more about the product quality and distribution quality. This conclusion shows that there are many kinds of fresh e-commerce on the market, and the competition is white hot. The most important factor for consumers to consider the distribution of fresh products is that the choice of factors is very unified. The choice speed is an important factor for the distribution of fresh products, accounting for $57 \%$, and the quality is $43 \%$. In terms of post purchase quality perception, logistics distribution perception, distribution service and quality, product quality or appearance degree, consumers hold positive opinions, and the opinions are mainly concentrated in comparative agreement and very agreement, and a few data have a neutral attitude. When the person in charge understands the attitude of low price, rich variety and accurate and safe information of online shopping products, a small proportion of data indicates that consumers do not agree with this expression. Therefore, some consumers hold negative opinions on the price of fresh e-commerce products, the variety of products, the accuracy and safety of online shopping information. The survey results are shown in Table 2.

Table2. Survey of consumer satisfaction and fresh e-commerce repeat purchase intension

\begin{tabular}{|c|c|c|c|}
\hline Title & Option & Frequency & Percentage \\
\hline \multirow{2}{*}{$\begin{array}{l}\text { How long is the best distribution time } \\
\text { after you placing the fresh food order? }\end{array}$} & Less than half an hour & 72 & 72.0 \\
\hline & $\begin{array}{c}\text { Arrive at the customization } \\
\text { time }\end{array}$ & 28 & 28.0 \\
\hline \multirow{4}{*}{$\begin{array}{l}\text { Frequency of purchasing fresh food } \\
\text { online }\end{array}$} & Once a week or more & 35 & 35.0 \\
\hline & Once half a month & 48 & 48.0 \\
\hline & Once a month & 8 & 8.0 \\
\hline & Purchase occasionally & 9 & 9.0 \\
\hline \multirow{2}{*}{$\begin{array}{l}\text { Which is the most likely reasons to } \\
\text { increase the purchase frequency of online } \\
\text { fresh products? }\end{array}$} & $\begin{array}{l}\text { Guaranteed quality of fresh } \\
\text { products }\end{array}$ & 24 & 24.0 \\
\hline & $\begin{array}{l}\text { Make a compromise between } \\
\text { quality and price }\end{array}$ & 76 & 76.0 \\
\hline \multirow{3}{*}{$\begin{array}{l}\text { Don't care whether it's a third-party } \\
\text { platform or a self-operated one. Pay } \\
\text { attention to delivery and product quality. }\end{array}$} & Neutral & 4 & 4.0 \\
\hline & Partly agree & 21 & 21.0 \\
\hline & Strongly agree & 75 & 75.0 \\
\hline \multirow{2}{*}{$\begin{array}{l}\text { What is the most important factor for the } \\
\text { distribution of fresh products }\end{array}$} & Speed & 57 & 57.0 \\
\hline & Quality & 43 & 43.0 \\
\hline \multirow{2}{*}{ Good quality perception after purchasing } & Partly agree & 44 & 44.0 \\
\hline & Strongly agree & 56 & 56.0 \\
\hline \multirow{2}{*}{$\begin{array}{c}\text { Good perception of logistics and } \\
\text { distribution }\end{array}$} & Partly agree & 49 & 49.0 \\
\hline & Strongly agree & 51 & 51.0 \\
\hline
\end{tabular}




\begin{tabular}{|c|c|c|c|}
\hline \multirow{3}{*}{ Good quality of distribution service } & Neutral & 13 & 13.0 \\
\hline & Partly agree & 13 & 13.0 \\
\hline & Strongly agree & 74 & 74.0 \\
\hline \multirow{3}{*}{ High quality of products } & Neutral & 35 & 35.0 \\
\hline & Partly agree & 52 & 52.0 \\
\hline & Strongly agree & 13 & 13.0 \\
\hline \multirow{4}{*}{ Low price of products } & Partly disagree & 20 & 20.0 \\
\hline & Neutral & 25 & 25.0 \\
\hline & Partly agree & 45 & 45.0 \\
\hline & Strongly agree & 10 & 10.0 \\
\hline \multirow{4}{*}{ Plenty varieties of products } & Partly disagree & 9 & 9.0 \\
\hline & Neutral & 23 & 23.0 \\
\hline & Partly agree & 48 & 48.0 \\
\hline & Strongly agree & 20 & 20.0 \\
\hline \multirow{4}{*}{$\begin{array}{l}\text { Accurate information of products } \\
\text { purchasing online }\end{array}$} & Partly disagree & 18 & 18.0 \\
\hline & Neutral & 45 & 45.0 \\
\hline & Partly agree & 30 & 30.0 \\
\hline & Strongly agree & 7 & 7.0 \\
\hline
\end{tabular}

In order to further study the relationship between gender, age, education background and "pay more attention to distribution and product quality, regardless of whether it is a third-party platform or self-supporting type", "good perception of post purchase quality", "good perception of logistics distribution", "high distribution service and quality", "high product quality or freshness", "low product price", "rich product types", "accurate and safe online shopping product information". However, in addition to gender and "distribution service and high quality", there is a significant positive correlation, the correlation between other variables is greater than 0.05 . There is no significant correlation, so it will not be described in detail.

In the survey of which fresh e-commerce platforms consumers have heard of, we found that many fresh ecommerce platforms are very well-known and recognized by consumers. In this survey, we did the survey consumer purchase experience and repeat purchase behavior by 8 fresh e-commerce as A, B, C, D, E, F, G, H. Among that, $B$ is the largest buyer of fresh products, followed by G, F and $\mathrm{C}$, which are more than half of the consumers surveyed. It can be seen from the purchase categories that the purchase proportion of refrigerated food, domestic fruits and vegetables, poultry and eggs, dairy products, pork, beef and mutton, and imported fruits is not small, while the purchase proportion of fresh vegetables is the smallest, only $26 \%$. The main reasons for choosing to buy fresh food online are convenience, time-saving and labour-saving. The coverage rate reaches $97 \%, 92 \%$ of them are rich in varieties, and $59 \%$ of them are cheap. However, only $22 \%$ of them choose to buy fresh food online because of better quality. When answering "are you willing to buy fresh products on the platform again", $92 \%$ of consumers choose "yes", and another $8 \%$ choose to buy fresh products on other platforms. On the one hand, it shows that the fresh e-commerce platform gives consumers a better shopping experience. The vast majority of consumers are willing to use the fresh ecommerce platform to buy, while $8 \%$ of consumers have a bad consumption experience in some aspects, but they do not give up the desire to buy the fresh e-commerce platform, just choose to use other platforms to buy. This also shows that the fresh e-commerce platform is highly competitive and consumers have a high choice, as shown in Table 3.

Table3. Survey of consumer purchase experience and repeat purchase behavior

\begin{tabular}{|c|c|c|c|}
\hline \multirow{4}{*}{ Title } & Option & Frequency & Percentage \\
\hline \multirow{3}{*}{$\begin{array}{c}\text { What fresh e-commerce platforms } \\
\text { do you know or have heard of? }\end{array}$} & $\mathrm{A}$ & 100 & 100.0 \\
\cline { 2 - 4 } & $\mathrm{B}$ & 100 & 100.0 \\
\cline { 2 - 4 } & $\mathrm{C}$ & 100 & 100.0 \\
\cline { 2 - 4 } & $\mathrm{D}$ & 100 & 100.0 \\
\cline { 2 - 4 } & $\mathrm{E}$ & 100 & 100.0 \\
\hline
\end{tabular}




\begin{tabular}{|c|c|c|c|}
\hline & $\mathrm{F}$ & 99 & 99.0 \\
\hline & $\mathrm{G}$ & 99 & 99.0 \\
\hline & $\mathrm{H}$ & 100 & 100.0 \\
\hline \multirow{8}{*}{$\begin{array}{l}\text { Which of the following fresh food } \\
\text { platforms do you often purchase } \\
\text { or plan to purchase? }\end{array}$} & A & 45 & 45.0 \\
\hline & B & 79 & 79.0 \\
\hline & $\mathrm{C}$ & 53 & 53.0 \\
\hline & $\mathrm{D}$ & 32 & 32.0 \\
\hline & $\mathrm{E}$ & 49 & 49.0 \\
\hline & $\mathrm{F}$ & 56 & 56.0 \\
\hline & G & 57 & 57.0 \\
\hline & $\mathrm{H}$ & 25 & 25.0 \\
\hline \multirow{8}{*}{$\begin{array}{l}\text { What kind of fresh food do you } \\
\text { buy online? }\end{array}$} & Imported fruit & 43 & 43.0 \\
\hline & Domestic fruit & 55 & 55.0 \\
\hline & Seafood and aquatic products & 47 & 47.0 \\
\hline & Meat, beef and mutton & 43 & 43.0 \\
\hline & Poultry and egg & 48 & 48.0 \\
\hline & Fresh vegetables & 26 & 26.0 \\
\hline & Refrigerated food & 57 & 57.0 \\
\hline & Dairy & 48 & 48.0 \\
\hline \multirow{4}{*}{$\begin{array}{l}\text { The main reason why you choose } \\
\text { to buy fresh food online }\end{array}$} & Low price & 59 & 59.0 \\
\hline & Save time and effort & 97 & 97.0 \\
\hline & $\begin{array}{l}\text { Plenty varieties of products which can't } \\
\text { be bought offline }\end{array}$ & 92 & 92.0 \\
\hline & $\begin{array}{l}\text { Imported and organic fruit have good } \\
\text { qualities }\end{array}$ & 22 & 22.0 \\
\hline \multirow{3}{*}{$\begin{array}{l}\text { Are you willing to buy fresh } \\
\text { products on fresh e-commerce } \\
\text { platform again? }\end{array}$} & Yes & 92 & 92.0 \\
\hline & No & 0 & 0.0 \\
\hline & Select other platforms & 8 & 8.0 \\
\hline
\end{tabular}

\section{Suggestions to increase consumer satisfaction and repeat purchase rate of fresh e-commerce}

\subsection{Strengthen the collection of user registration information and establish a good consumer community}

At present, fresh e-commerce apps need to be registered before they can be used. At the same time, in order to better promote the establishment of the community, promotion policies such as inviting new customers to get preferential or red envelope rewards often appear. On the one hand, this undoubtedly increases the number of registered e-commerce users, but on the other hand, new users are constantly invited to register new members, which inevitably leads to the aversion of fee price sensitive users. This kind of invitation to register for preferential way is more to attract some price sensitive or relatively older consumer groups. However, from the perspective of consumer groups, young and middle-aged registered users of fresh e-commerce are the main consumer groups. Therefore, this kind of promotion means of inviting for preferential treatment may not be able to attract the recognition of consumers of this age group. Young and middle-aged people have their own information needs. They are not necessarily price sensitive customers, but they have communication needs related to job promotion, child rearing and education, and improvement of life quality. Therefore, it is necessary for fresh e-commerce app to increase the information collection of registered users, establish a consumer community for them through certain data calculus, and provide information exchange. For example, Fresh Hema has the "box area life" section, where you can exchange the content of how to cook the products purchased by Fresh Hema e-commerce app and make delicious food for your family. On the one hand, we buy and do it one after another. On the other hand, we get points or discounts through information release and exchange to purchase goods. 


\subsection{Understand the shopping habits of consumers and carry out personalized customized promotion}

Preferential promotion is one of the means to improve consumer satisfaction and repeat purchase rate. However, the number of red packets is too much to choose, or the type of red packets has nothing to do with consumption habits, but will cause consumer disgust. Appropriate amount of red envelope or promotion incentive policy can improve the satisfaction of consumers and increase the repeat purchase rate. This kind of moderate and appropriate preferential promotion incentive policy can be customized through the consumption habits of consumers mastered by the fresh e-commerce platform. With the advent of the era of big data, fresh e-commerce platform can easily understand the consumption habits of consumers, and the e-commerce platform with a good grasp of data mining and data analysis is easier to understand the consumption habits of users. How long you will buy dairy products, what brand of dairy products you are used to buying, and whether there are other related buying habits can be collected and analysed from the consumption data. To provide consumers with appropriate discount or package promotion price in a cycle can not only improve the repeat purchase rate of consumers, but also effectively improve the satisfaction of consumers, from ordinary registered users to loyal customers. This kind of personalized customized promotion can better attract price sensitive consumers to re purchase.

\subsection{Reduce the error rate of picking and strengthen the reasonable packaging of fresh products}

Fresh e-commerce platforms mostly rely on manual selection. Due to the minimum amount of free mail, consumers tend to buy more products at one time, which causes great pressure on commodity selection. Especially when there are many orders and a large amount of tasks, different brands and specifications of the same kind of goods are easy to cause picking errors. On the one hand, this kind of mistake may cause the loss of the business, on the other hand, it will bring the decline of consumer satisfaction, and even make bad comments on the goods or logistics, which will affect not only the repeat purchase rate of the consumers, but also the reputation of the business. Therefore, it is particularly easy to reduce the picking error rate in the links of commodity transportation and packaging. At the same time, consumers mainly buy fresh products in fresh e-commerce. As consumers have higher and higher requirements for food safety, the demand for subcontracting and repackaging of fresh products has increased significantly. Fresh vegetables, fresh fruits, frozen food, raw meat, seafood and aquatic products, milk, eggs and milk, and even other ready to eat products all need to be packed separately, and according to whether the requirements of cold chain distribution are different, different special boxes or bags for cold chain distribution need to be used. Fresh e-commerce is a professional store in the field of fresh food. We should not cut corners on fresh packaging because we want to save trouble or to be cheap. This will not only reduce consumers' trust in fresh e-commerce, thus affecting the repeat purchase rate, but also affect the word-of-mouth of fresh e-commerce specialization.

\subsection{Increase and expand the content and field of consumer services, and improve consumers' favour of fresh e-commerce brand}

Fresh e-commerce is more convenient to browse and obtain information, and it is better than traditional super shopping methods in information release and exchange. Therefore, the service content and field of registered users of fresh e-commerce can be moderately increased and expanded. The "Double Eleven" and "Double Twelve" of China's e-commerce have become the online shopping feast of consumers. And fresh e-commerce can also use the planning of special activities to stimulate consumers' repeat purchase rate of fresh online shopping. For example, according to the "Seasonal Special Topic" launched by the twenty-four solar terms, it introduces dishes and foods, recommends tonic ingredients; plans the "Food Festival at Home" to introduce local traditional food, and provides food discount links; designs "a daily seasonal dish", teaches a simple and easy to learn home dish every day, provides home dish bags or even semi-finished products, and provides home delivery service before meals, etc, Improve the participation of consumers, so that fresh ecommerce can truly integrate into the family life of consumers, and become the "small tool" and "small helper" of consumers at home.

\subsection{Develop appropriate member level upgrade strategy to improve member repeat purchase rate}

It is very important to make a suitable strategy to upgrade the membership level to improve the repeat purchase rate. Member level upgrade strategy is different from the new user registration discount or consumption red envelope experience. The pertinence of member level upgrade strategy is to improve consumers' repeat purchase. According to the amount and frequency of consumer purchase, improve the consumer's membership level, and give certain preferential promotion activities. Different levels of members can enjoy different promotional services, the higher the level of consumers, the more promotional efforts. For example, it can provide personalized customized housekeeping services, a fixed number of weekly free mail delivery services, no reason returns and exchange services, customized personalized products, shop mascot dolls or customized shopping bags, game breakthrough and lucky draw, etc. to enhance the membership level, enjoy VIP treatment, and stimulate consumers to purchase repeatedly.

\section{Conclusion}

This paper based on the literature research of consumer satisfaction and fresh e-commerce repeat purchase behavior, through the investigation of online shopping 
experience of consumers using fresh e-commerce and empirical research on the relationship between consumer satisfaction and fresh e-commerce repeat purchase, this paper puts forward 5 suggestions to improve consumer satisfaction and increase fresh e-commerce repeat purchase rate, such as strengthen the collection of user registration information and establish a good consumer community, understand the shopping habits of consumers and carry out personalized customized promotion, reduce the error rate of picking and strengthen the reasonable packaging of fresh products, increase and expand the content and field of consumer services and improve consumers' favour of fresh e-commerce brand, and develop appropriate member level upgrade strategy to improve member repeat purchase rate. These important suggestions have huge effects for improve consumer satisfaction and increase fresh e-commerce repeat purchase rate, help fresh e-commerce gain market competitiveness and achieve market share.

\section{References}

1. Jing Liu. Study On Customer Satisfaction Evaluation Model Based On Analytic Hierarchy Process Method [D]. Shanghai Jiao Tong University, 2011.

2. Kim S Y, Lim Y J. Consumer Perceived Importance of and Satisfaction with Internet Shopping[J]. Electronic Markets, 2001, 11(03):148-154.

3. Kezhen Zhang. Fuzzy comprehensive evaluation of fresh e-commerce platform consumer satisfaction based on AHP $[\mathrm{J}]$. China management informatization, 2020 (10): 153-156.

4. Yun Wang. An empirical study on the influencing factors of fresh e-commerce customer satisfaction [J]. Commercial exhibition economy, 2021 (2): 38-40.

5. Cao Huarui. Study on How Consumers' Perception of Logistics Distribution Service Quality in Online Shopping Influences Their Attitudes and Postpurchasing Behaviors [J]. Logistics Technology, 2014, 33(9): 131-133.

6. Yinghong Shi. Research on the perception of urban fresh e-commerce distribution service quality and re purchase hospital [D]. Jiangsu: Suzhou University, 2020.

7. Wenxiang Xing, Hua Han. Research on Influencing Factors of repeat buying behavior of e-commerce consumers [J]. Academic forum, 2014 (11): 67-71.

8. Zuoliang Ye, Xueqiao Wang, Bao Zhihong, et al. Empirical study and modeling of repeat buying behavior in $\mathrm{C} 2 \mathrm{C}$ environment $[\mathrm{J}]$. Journal of management science, 2011 (12): 71-78.

9. Ye Zuoliang, Wang Xueqiao, Bao Zhihong, et al. Modeling and empirical research of repeat purchase behavior in $\mathrm{C} 2 \mathrm{C}$ ecommerce[J]. Journal of Management Sciences in China, 2011, 14(12): 71-78.

10. Sheng Jiping, Shi Hongxu. Analysis on determinants of consumers' intention to repeat-purchase fresh fruits online from the perspective of attachment [J]. Journal of Food Safety and Quality, 2019,10(24): 8358-8363.
11. Harun A, Mahmud M, Othman B, et al. Understanding experienced consumers towards repeat purchase of counterfeit products: The mediating effect of attitude[J]. Management Science Letters, 2019, 10(1): 1-16.

12. Fahmi M, Arif M, Farisi S, et al. Peran Brand Image dalam Memediasi Pengaruh Social Media Marketing terhadap Repeat Purchase pada Fast-Food Restaurant di Kota Medan[J]. Jurnal Samudra Ekonomi dan Bisnis, 2019, 11(1):53-68.

13. Kunamaneni S, Jassi S, Hoang D. Promoting reuse behaviour: Challenges and strategies for repeat purchase, low-involvement products[J]. Sustainable Production and Consumption, 2019, 20(10): 253-272.

14. Lewers K S, Castro P, Hancock J F, et al. Evidence of epistatic suppression of repeat fruiting in cultivated strawberry[J]. BMC Plant Biology, 2019, 19(1): 1-18.

15. Lewers K S, Newell M J, Park E, et al. Consumer preference and physiochemical analyses of fresh strawberries from ten cultivars[J]. International Journal of Fruit Science, 2020, 20(2): 1-24. 